\title{
Tree Growth, Yield, and Fruit Quality of Ortanique Tangor on Eleven Rootstocks in Cyprus
}

\author{
C. Gregoriou ${ }^{1}$ and C.V. Economides ${ }^{2}$ \\ Agricultural Research Institute, P.O. Box 2016, Nicosia, Cyprus
}

Additional index words. Citrus reticulata, fruit weight, juice content, rind thickness, total acid, soluble solids concentration

\begin{abstract}
Growth, yield, and fruit quality were recorded for Ortanique tangor (Citrus reticulata Blanco) on 11 rootstocks until the trees were 12 years old. Trees on Volkameriana ( $C$. volkameriana Pasq.), rough lemon, and 'Estes rough lemon (C. jambhiri Lush.) were more productive per unit of tree size, and their cumulative yields per tree were significantly higher than those of trees on the other rootstocks. There was no significant difference between cumulative yields of Ortanique on the following rootstocks: sour orange $(C$. aurantium $\mathrm{L}$.), 'Palestine' sweet lime (C. limettioides Tan.), 'Red' rough lemon $(C$. jambhiri Lush.), Rangpur (C. limonia Osbeck), and Amblycarpa (C. limonellus var. amblycarpa Hassk.). However, yield on these rootstocks was significantly higher than on Carrizo and Troyer citranges $[C$. sinensis $(\mathrm{L}$.) Osbeck $\times$ Poncirus trifoliata (L.) Raf.] and 'Swingle' citrumelo [C. paradisi Macf. $\times$ P. trifoliata (L.) Raf.]. The high productivity per unit of tree size of 'Palestine' sweet lime suggested that this rootstock could be used advantageously in closely spaced plantings. Rootstocks affected fruit size, weight, rind thickness, juice content, total soluble solids concentration (SSC), and total acids, but the differences were not large enough to be of practical importance.
\end{abstract}

Citrus is one of the most important crops in Cyprus. In 1990 it occupied 7300 ha or $20 \%$ of the total irrigated land. Citrus production in 1990 reached $170,000 \mathrm{t}$ of which $30 \%$ was oranges, $40 \%$ grapefruit, $22 \%$ lemons, and $5 \%$ mandarins. Ortanique is a new crop for Cyprus but has expanded rapidly during the last few years as a result of the high demand in the export market.

The origin of this attractive and promising variety is unknown, but Ortanique is reported (Jamaica Citrus Growers Assn., 1963) to be an old chance seedling that came to the attention of C.P. Jackson of Chellaston, Mandeville, Jamaica, in 1920. Because of the presence of wild orange and so-called tangerine trees in the vicinity of the original tree, and the distinctive features of the fruit, it was considered to be a natural tangor and was given the name Ortanique by H.H. Cousins. The name was a synthesis coined from or(ange), $\tan$ (gerine), and (un)ique. The present clone probably represents a nucellar seedling of the parent tree (Hodgson, 1967).

In Cyprus, all citrus varieties are mainly budded on sour orange, which generally is the most commonly used rootstock, particularly in the Mediterranean region. Although sour orange was considered a satisfactory rootstock in several citrus-producing areas such as South Africa, South America (Brazil, Argentina), Florida, Texas, and a part of California, it had to be replaced in some of these areas as a result of its susceptibility to citrus tristeza virus (Wallace, 1956a, 1956b; Salibe, 1973).

The occurrence of tristeza in the Mediterranean area (Bitters, 1973; Mendel, 1956) and its detection in Cyprus (Kyriakou and Polykarpou, 1989; Papasolomontos and Economides, 1968) have stimulated a search for alternative rootstocks. The currently limited presence of tristeza in Cyprus does not preclude the possibility that the disease will not become a problem in the future.

As an assurance for future plantings, a research program was initiated in Cyprus to find a suitable rootstock to replace sour orange if tristeza becomes epidemic. We here present data on the

Received for publication 10 Mar. 1992. Accepted for publication 24 Oct. 1992. Research conducted at Akhelia Research Station of the Agricultural Research Institute. The cost of publishing this paper was defrayed in part by the payment of page charges. Under postal regulations, this paper therefore must be hereby marked advertisement solely to indicate this fact.

'Agricultural Research Officer 'A'.

${ }^{2}$ Senior Agricultural Research Officer. performance of eleven rootstocks, as measured by growth, yield, and fruit quality.

\section{Materials and Methods}

The rootstocks used were: sour orange, 'Palestine' sweet lime, rough lemon, 'Red' rough lemon, 'Estes' rough lemon, Rangpur, Troyer and Carrizo citranges, 'Swingle' citrumelo, Volkameriana and Ambly-carpa.

Seeds were obtained from Willits and Newcomb, Arvin, Calif., except for sour orange and 'Palestine' sweet lime seeds, which were obtained locally from selected healthy trees planted in Mar. 1976. The seedlings were planted in the nursery at the Paphos Experimental Station in Mar. 1977, and were budded in Oct. 1978, with buds from a single tree of Ortanique. The trees were grown in the nursery using standard practices and were planted in Mar. 1980 in a randomized block design with two-tree plots of each rootstock replicated six times. Tree spacing was $6.6 \mathrm{~m}$ between rows and 4.2 $\mathrm{m}$ within rows. The budding material had been imported from California in 1972 and was free of diseases known at the time. At some later stage, however, it must have become infected with the citrus exocortis viroid. Samples taken from the experimental block and indexed on several plant indicators were negative for tristeza, psorosis, vein enation virus, and citrus cachexia viroid, but were positive for exocortis viroid, since they produced severe symptoms on citron (Citrus medica L.) and Gynura aurantica D.C. (A. Kyriakou, unpublished data).

The soil was clayey ( $60 \%$ clay, $25 \%$ silt, $15 \%$ sand), contained $20 \% \mathrm{CaCO}_{3}$, had a $\mathrm{pH}$ value of 8.0 (1 soil : 2.5 water), and an $\mathrm{EC}_{\mathrm{e}}$ value of $1.5 \mathrm{dS} \cdot \mathrm{m}^{-1}$ throughout the profile.

The area has an average annual rainfall of $460 \mathrm{~mm}$, occurring mainly from October to April, and mean maxima air ranging from $17 \mathrm{C}$ in January to $31 \mathrm{C}$ in July, and mean minima from 9 to $22 \mathrm{C}$. Relative humidity ranges from $60 \%$ to $75 \%$.

A total of $\approx 25$ irrigations were applied per year at weekly intervals during each irrigation season with microjets delivering 700 liters of water per tree at each application in the last year of the experiment. The water had a $\mathrm{pH}$ of 7.6 and an electrical conductivity of $0.7 \mathrm{dS} \cdot \mathrm{m}^{-1}$. It contained (in ppm): $\mathrm{Cl}-53$; Na-57; Ca-58; $\mathrm{Mg}$ 20; $\mathrm{SO}_{4}-134$; and $\mathrm{HCO}_{3}-128$.

One month before flowering, ammonium sulphate, triple super- 
phosphate, and potassium sulphate were applied in amounts increasing progressively each year to a maximum of $3.0,0.5$, and 1.0 $\mathrm{kg}$ per tree, respectively. The grove was cultivated, pruned, and sprayed with insecticides and fungicides, according to local practices.

Trunk cross-sectional area (TCSA) was recorded $15 \mathrm{~cm}$ above the bud union in Oct. 1991. Fruit were harvested in the middle of February, and yields were expressed on a tree basis. Samples (10 fruit from each tree) for fruit size and quality measurements were taken from 1987 to 1991. Each fruit was weighed and cut in half. Rind thickness was measured with a digital caliper, and the juice was extracted with an electric juicer. Total SSC was measured with a temperature-compensated refractometer, and total acids were determined (as citric acid equivalent) by titrating with $\mathrm{NaOH}$.

\section{Results and Discussion}

TCSA measurements indicated that trees on Amblycarpa were the largest, while those on sour orange, rough lemon, 'Estes' rough lemon, Rangpur, and Volkameriana were smaller and did not differ significantly from each other (Table 1). The smallest trees were those on Troyer and Carrizo citranges, but they did not differ significantly from trees on 'Swingle' citrumelo, 'Palestine' sweet lime, and red rough lemon.

The trees on Rangpur, 'Swingle' citrumelo, Troyer, and Carrizo citranges developed a severe overgrowth of the rootstock as compared to the scion, whereas 'Palestine' sweet lime and Amplycarpa rootstocks were only slightly larger than the scion. Trees on other rootstocks had normal bud unions. Trees on 'Palestine' sweet lime, Rangpur, 'Swingle' citrumello, Carrizo, and Troyer citrange exhibited mild to moderate bark cracking below the bud union as a result of the presence of exocortis.

Trees on all rootstocks showed a general yield increase until 1987 (Table 1). In 1988, however, yield was generally lower, whereas in 1989, yield increased again. Trees on sour orange, rough lemon, Rangpur, Troyer and Carrizo citranges, 'Swingle' citrumelo, and Amblycarpa had an increase in production in 1990 and a decrease in 1991, whereas trees on 'Palestine' sweet lime, 'Red' rough lemon, 'Estes' rough lemon, and Volkameriana had a decrease in 1990 and an increase in 1991. This variability in production of trees on the various rootstocks probably reflects a tendency to biennial bearing. However, trees on rough lemon, 'Estes' rough lemon, and Volkameriana had significantly higher yield in almost all years than trees on other rootstocks.

Volkameriana, rough lemon, and 'Estes' rough lemon were clearly the best rootstocks in the present trial in terms of yields (Table 1). During the 8-year production period cumulative, yields of trees on Volkameriana, rough lemon, and 'Estes' rough lemon were $47 \%, 44 \%$, and $35 \%$ higher than those on sour orange. Cumulative yields of trees on sour orange, 'Palestine', sweet lime, red rough lemon, Rangpur, and Amblycarpa did not differ significantly, but they were more productive than trees on Troyer and Carrizo citranges and 'Swingle' citrumelo. Troyer citrange was the least productive rootstock, but did not differ significantly from 'Swingle' citrumelo. In Jamaica, Ortanique trees on sour orange yielded as well as trees on rough lemon and Rangpur rootstocks and better than on Troyer citrange, Cleopatra mandarin, and trifoliate orange (Weir, 1976).

The relatively small tree size and low yield of trees on Troyer and Carrizo citranges and 'Swingle' citrumelo were probably due to the high soil $\mathrm{pH}$ and $\mathrm{CaCO}_{3}$ content. In addition, the presence of citrus exocortis likely had a negative effect on the performance of the trees on these rootstocks (Bitters et al., 1954). This effect will be increasing with time as symptoms of exocortis will become more severe. However, yield of trees on 'Palestine' sweet lime and Rangpur was relatively high, although citrus exocortis produced bark cracking of these trees.

The correlation coefficient between trunk cross section and the yield was not significant $(r=0.44, P=0.18)$. However, yield efficiency (yield per TCSA) of trees on 'Palestine' sweet lime, rough lemon, 'Estes' rough lemon and Volkameriana, significantly exceeded that of all other rootstocks (Table 1). Because of

Table 1. Effect of rootstock on trunk cross-sectional area (TCSA) and yield of Ortanique tangor trees.

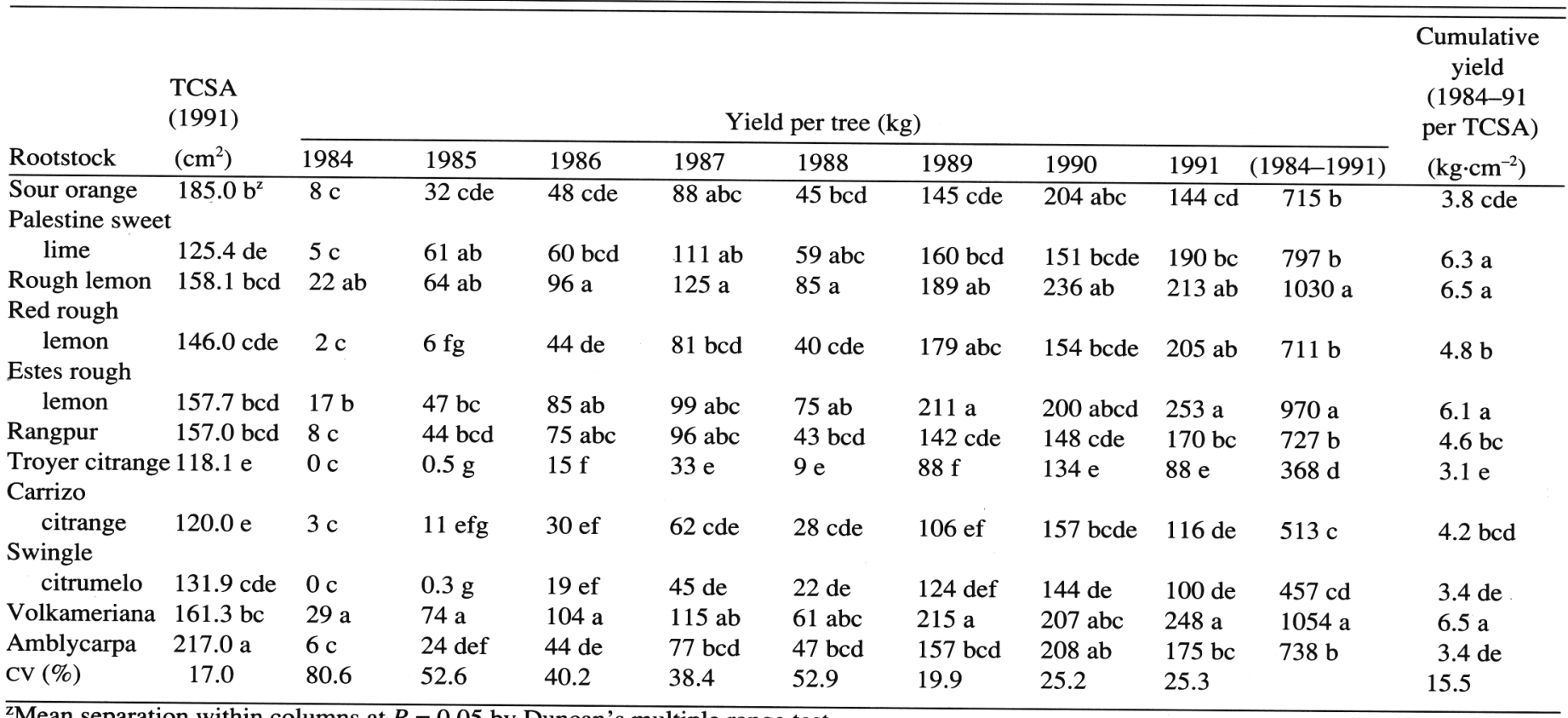

${ }^{\mathrm{z}}$ Mean separation within columns at $P=0.05$ by Duncan's multiple range test. 
Table 2. Fruit size, weight, and rind thickness of Ortanique tangor trees budded on various rootstocks (1987-91 means).

\begin{tabular}{lccc}
\hline \hline Rootstock & $\begin{array}{c}\text { Fruit diam } \\
(\mathrm{cm})\end{array}$ & $\begin{array}{c}\text { Fruit wt } \\
(\mathrm{g})\end{array}$ & $\begin{array}{c}\text { Rind thickness } \\
(\mathrm{mm})\end{array}$ \\
\hline Sour orange & 8.25 & $231 \mathrm{~cd}$ & $4.1 \mathrm{bc}$ \\
Palestine sweet lime & $9.01 \mathrm{ab}$ & $294 \mathrm{a}$ & $4.5 \mathrm{ab}$ \\
Rough lemon & $8.66 \mathrm{bc}$ & $255 \mathrm{bc}$ & $4.5 \mathrm{ab}$ \\
Red rough lemon & $9.16 \mathrm{a}$ & $303 \mathrm{a}$ & $4.8 \mathrm{a}$ \\
Estes rough lemon & $8.65 \mathrm{bc}$ & $258 \mathrm{bc}$ & $4.5 \mathrm{ab}$ \\
Rangpur & $9.06 \mathrm{ab}$ & $274 \mathrm{ab}$ & $5.0 \mathrm{a}$ \\
Troyer citrange & $8.11 \mathrm{~d}$ & $216 \mathrm{~d}$ & $3.8 \mathrm{c}$ \\
Carrizo citrange & $8.13 \mathrm{~d}$ & $221 \mathrm{~cd}$ & $4.0 \mathrm{bc}$ \\
Swingle citrumelo & $8.30 \mathrm{~cd}$ & $233 \mathrm{~cd}$ & $4.0 \mathrm{bc}$ \\
Volkameriana & $8.88 \mathrm{ab}$ & $275 \mathrm{ab}$ & $3.8 \mathrm{c}$ \\
Amblycarpa & $8.66 \mathrm{bc}$ & $249 \mathrm{bcd}$ & $4.0 \mathrm{bc}$ \\
CV $(\%)$ & 3.9 & 11.2 & 12.1
\end{tabular}

${ }^{\mathrm{z}}$ Mean separation within columns at $P=0.05$ by Duncan's multiple range test.

Table 3. Effect of rootstock on fruit quality of Ortanique tangor trees (1987-91 means).

\begin{tabular}{lcccc}
\hline \hline Rootstock & $\begin{array}{c}\text { Juice } \\
\text { by wt } \\
(\%)\end{array}$ & $\begin{array}{c}\text { Total soluble } \\
\text { solids concn (SSC) } \\
(\%)\end{array}$ & $\begin{array}{c}\text { Total acids } \\
(\text { TA }) \\
(\%)\end{array}$ & $\begin{array}{c}\text { SSC : TA } \\
\text { ratio }\end{array}$ \\
\hline Sour orange & $52.8 \mathrm{~b}^{\mathrm{z}}$ & $12.8 \mathrm{a}$ & $2.0 \mathrm{a}$ & $6.4 \mathrm{~b}$ \\
Palestine sweet lime & $52.3 \mathrm{~b}$ & $11.1 \mathrm{de}$ & $1.4 \mathrm{bc}$ & $7.9 \mathrm{a}$ \\
Rough lemon & $49.0 \mathrm{c}$ & $11.2 \mathrm{de}$ & $1.5 \mathrm{bc}$ & $7.6 \mathrm{a}$ \\
Red rough lemon & $46.4 \mathrm{c}$ & $11.1 \mathrm{e}$ & $1.3 \mathrm{c}$ & $8.4 \mathrm{a}$ \\
Estes rough lemon & $52.9 \mathrm{~b}$ & $11.2 \mathrm{de}$ & $1.5 \mathrm{bc}$ & $7.4 \mathrm{ab}$ \\
Rangpur & $47.9 \mathrm{c}$ & $11.2 \mathrm{de}$ & $1.5 \mathrm{bc}$ & $7.5 \mathrm{a}$ \\
Troyer citrange & $56.5 \mathrm{a}$ & $12.1 \mathrm{bc}$ & $1.6 \mathrm{~b}$ & $7.4 \mathrm{ab}$ \\
Carrizo citrage & $57.5 \mathrm{a}$ & $12.4 \mathrm{ab}$ & $1.6 \mathrm{~b}$ & $7.8 \mathrm{a}$ \\
Swingle citrumelo & $55.0 \mathrm{ab}$ & $11.7 \mathrm{~cd}$ & $1.4 \mathrm{bc}$ & $8.3 \mathrm{a}$ \\
Volkameriana & $52.5 \mathrm{~b}$ & $11.9 \mathrm{bc}$ & $1.5 \mathrm{bc}$ & $8.0 \mathrm{a}$ \\
Amblycarpa & $56.0 \mathrm{a}$ & $11.9 \mathrm{bc}$ & $1.5 \mathrm{bc}$ & $7.8 \mathrm{a}$ \\
CV $(\%)$ & 4.8 & 4.14 & 10.9 & 11.3 \\
\hline
\end{tabular}

${ }^{\mathrm{z}}$ Mean separation within columns at $P=0.05$ by Duncan's multiple range test.

their smaller size, trees on 'Palestine' sweet lime may be planted more closely and yield equally well as largertrees on Volkameriana, rough lemon, and 'Estes' rough lemon.

The largest and heaviest fruit were produced by trees on red rough lemon, Rangpur, 'Palestine' sweet lime, and Volkameriana, whereas trees on Troyer and Carrizo citranges, 'Swingle' citrumello, and sour orange produced fruit that had a significantly smaller diameter and weighed less, although there was some overlap with intermediately productive rootstocks (Table 2). Trees on Rangpur, rough lemon, red rough lemon, 'Estes' rough lemon, and 'Palestine' sweet lime produced fruit with a significantly thicker rind than trees on Troyer citrange and Volkameriana. Rind thickness of fruit from trees on the other rootstocks was intermediate.

Trees on Carrizo and Troyer citranges and Amblycarpa produced fruit with the highest juice content, whereas trees on red rough lemon, Rangpur, and rough lemon produced the lowest (Table 3). Trees on sour orange produced the highest SSC, and trees on sour orange induced a higher total acid content than trees on any other rootstock. The sugar : acid ratio was lowest for sour orange, but it did not differ from that for 'Estes' rough lemon or Troyer citrange. The other rootstocks had similar ratios.

Although it is well known that fruit quality is at times markedly influenced by rootstocks, our observations did not reveal differences that could affect the market value of the fruit when harvested at dates used in this study. But it is quite possible that the magnitude of differences observed was sufficient to affect dates of earliest picking and the storage of fruit on the trees.

Tristeza is present in Cyprus, but apparently not in an epidemic form (Kyriakou and Polykarpou, 1989; Papasolomontos and Economides, 1968). This fact, however, does not mean that the disease may not become a serious problem in the future. Since sour orange, the standard rootstock commercially used in Cyprus, is highly susceptible to tristeza, consideration must be given to tristeza-tolerant rootstocks with good yielding potential of quality fruit to replace sour orange in future plantings. On the basis of our work, Volkameriana, rough lemon, and 'Estes' rough lemon deserve more attention in the future because a substantial increase in Ortanique production is possible with these rootstocks. However, final conclusions concerning the adoption of any new rootstocks will emerge only after extended trials under a range of commercial growing conditions.

\section{Literature Cited}

Bitters, W.P., J.A. Brusca, and N.W. Dukershire, 1954. Exocortis transmission tests. California Agr. 8(4):4-5.

Bitters, W.P. 1973. World citrus rootstock situation. Proc. 1st Intl. Citrus Short Course, Univ. of Florida, p. 1-14.

Hodgson R.W. 1967. Horticultural varieties of citrus, p. 431-586. In: W. Reuter, H.J. Webber, and L.D. Batchelor (eds.). The Citrus Ind. vol. I, Univ. of California Press, Berkeley. 
Jamaica Citrus Growers Assn.. 1963. Ortaniques 3 pp. (Mimeo).

Kyriakou, A. and D. Polykarpou. 1989. Detection of citrus tristeza in Cyprus. Mediterranean Crop Improvement Council, News 12,3-4.

Mendel, K. 1956. The threat of tristeza in the Mediterranean basin. Food Agr. Organization Plant Protection Bul. vol. 4 (7):106-108.

Papasolomontos A. and C.V. Economides, 1968. The presence of tristeza virus in certain species of citrus in Cyprus. Food Agr. Organization Plant. Protection Bul. vol. 16:8-9.

Salibe, A.A. 1973. The tristeza disease. Proc. 1st Intl. Citrus Short Course,
Univ. of Florida, p. 68-76.

Wallace, J.M. 1956a. Tristeza disease of citrus with special reference to its situation in the United States. Food Agr. Organization Plant Prot. Bul. vol. 10(8):77-78.

Wallace, J.M. 1956b. Tristeza and stem-pitting disease of citrus in South Africa. Food Agr. Organization Plant Protection Bul. vol. 10(8):88-94.

Weir, C.C. 1976. Effect of various rootstocks on the growth and yield of Valencia orange, Marsh Seedless grapefruit, and Ortanique trees in Jamaica. Journal Agr. Univ. Puerto Rico 1976 60(4):485-490. 